\title{
Tribute to Professor H. Stobbe
}

On the 17th of February, 1995, Professor Horst Stobbe, celebrated his seventy-fifth birthday. His influence in the fields of hematology and oncology has made itself felt well beyond the boundaries of the former German Democratic Republic. For many years his Atlas of Hematology and excellent textbooks were valuable standard works for teaching and reference in the former West Germany.

Over 300 scientific publications bear witness to the thoroughness of his work on problems of hematology and oncology, and he supervised more than a hundred and thirty dissertations. Much of his writing was devoted to phase-contrast examination of vital blood and bone marrow cells. In this way he developed, among several other innovations, a method of rapid diagnosis of malaria by phase-contrast microscopy, and described different stages of mobility during the maturation of reticulo-cytes. In particular, he concentrated on finding ways to distinguish between primary thrombocytosis and polycythemia vera, osteomyelosclerosis and chronic myelocytic leukemia. In 1971 he compiled a catalogue of diagnostic and therapeutic procedural guidelines for the maintenance of standards in hematological work. In so doing, he anticipated by more than twenty years the requirements of current health policy. During his last years of research activity at the Charité Hospital he carried out experiments to examine the proliferation of hemo-poietic stem cells. Afterwards, this line of enquiry was successfully pursued by his former colleagues.

Professor Stobbe was born in Breslau in 1920, where he studied medicine and took his degree. Subsequently he was assistant to Professor Carl Seyffert at St. George's Hospital in Leipzig, and then transferred to the Institute of Pathology and Bacteriology there. In 1953 he was appointed to the 1st Medical Clinic of Charité by Professor Brugsch, where he built up the hematology department and later took over its direction. With his thesis on 'The Plasma Cell' he obtained his doctorate in 1960, and qualified for university lectureship. In 1964 he was appointed visiting professor and in 1969 full professor. Right up to the time of his retirement from active duties, he labored tirelessly in the cause of science, the care of patients and the teaching of hematology. He has been honored in many ways for his scientific work in both research and clinical spheres and was, for instance, awarded the Virchow Prize and the Hufeland Medal. For years he served as President of the German Society of Hematology and Transfusion, finally being nominated Honorary President of both the latter and the Society for Internal Medicine. Professor Stobbe has remained active as internist and hemato-oncologist since retiring and has been able to complete the latest edition of his textbook, 'General and Specific Treatment of Diseases of the Internal Organs'.

With best wishes for many more years of good health and uninterrupted creativity K. Possinger, Berlin

Iscador® M 5 mg spezial ISCfldø $\Gamma^{*}$ Wirkstoff: Fermentierter wäßriger Auszug aus Apfelbaummistel. 
Zusammensetzung: 1 Ampulle enth.: Fer-mentierten wäßrigen Auszug aus 5 mg Viscum album ssp. album (Apfelbaummistel) Herba rec. (Pflanze zu Auszug = 1 :5). Sonstige Bestandteile: Natriumchlo-rid, Natriumhydroxid, Wasser. Anwendungsgebiete gemäß der anthroposophischen Menschen- und Naturer-kenntnis.

Dazu gehören: Bösartige und gutartige Geschwulsterkrankungen; bösartige Er-krankungen und begleitende Störungen der blutbildenden Organe; Anregung der Knochenmarkstätigkeit; Vorbeugung ge-gen Geschwulstrezidive; definierte Prä-kanzerosen.

Gegenanzei ${ }^{3} / 4$ en: Bekannte Allergie auf Iscador*: Eine Fortsetzung der Therapie ist erst nach erfolgter Desensibilisierungsbe-handlung mit einschleichender Dosierung möglich. Akut entzündliche bzw. hoch

fieberhafte Erkrankungen (Körpertem-peratur über $38^{\circ} \mathrm{C}$ ): Die Behandlung soll-te bis zum Abklingen der Entzündungs-zeichen unterbroche` werden. Tuberku-lose. Hyperthyreose mit nicht ausgegli-chener Stoffwechsellage. Primäre Hirn-und Rückenmarkstumoren oder intracranielle Metastasen mit Gefahr einer Hirn-druckerhöhung: In diesem Fall sollte Iscador ${ }^{\circledR}$ M 5 mg spezial vorsichtig verab-reicht werden. Schwangerschaft: Bisher sind keine Wirkungen bekannt geworden, die gegen eine Anwendung von Iscador* M $5 \mathrm{mg}$ spezial in der Schwangerschaft sprechen. Aus Gründen besonderer Vor-sicht sollte Iscador ${ }^{\circledR}$ M 5 mg spezial je-doch während der Schwangerschaft nur nach strenger Indikationsstellung verab-reicht werden.

Nebenwirkungen: Eine leichte Steigerung der Körpertemperatur sowie örtlich be-grenzte entzündliche Reaktionen urn die Einstichstelle der subcutanen Injektion sind u $\mathrm{n}$ bedenklich und ein Zeichen des Ansprechens des Patienten auf die verab-

reichte Dosis. Das durch lscador*-lnjek-tionen hervorgerufene Fieber soil nicht durch antipyretisch wirkende Substanzen unterdrückt werden. Bei Fieber über $38^{\circ} \mathrm{C}$ (evtl. mit Abgeschlagenheit, Frösteln, allgemeinem Krankheitsgefühl, Kopf-schmerzen und kurzzeitigen Schwin-delanfällen) oder bei größeren örtlichen Reaktionen über $5 \mathrm{~cm}$ Durchmesser sollte die nächste Injektion erst nach Abklingen dieser Symptome und in reduzierter Kon-zentration bzw. Dosis gegeben werden. Bei länger als drei Tage anhaltendem Fieber ist an einen infektiösen Prozeß oder Tumorfieber zu denken. In seltenen Fallen können örtliche oder allgemeine allergische oder allergoide Reaktionen (Urticaria, generalisierter Pruritus, lokale oder generalisierte

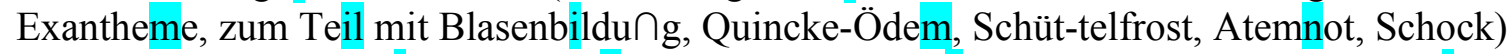
auftreten, die ein sofortiges Absetzen des Präparates und àrztliche Behandlung erforderlich machen. Eine Fortsetzung der Therapie ist erst nach erfolgter DesensibilisierungsbeANZEIGE

handlung mit einschleichender Dosierung möglich. Eventuell ist auch der Wechsel auf Iscador ${ }^{\circledR}$ eines anderen Wirtsbaumes erforderlich. Knotenbildung am Injekti-onsort bei subcutaner Injektion. Thrombophlebitis bei versehentlicher intravenö-ser Injektion. Hïndruckerhöhung bei primären Hirn- und Rückenmarkstumoren oder intracraniellen Metastasen (siehe auch unter „Gegenanzeigen”).

Darreichungsform und Packungsgröße: 8 Ampullen zu 1 ml Injektionslösung. Iscador ${ }^{\circledR}$ M 5 mg spezial ist eines der Präparate, die wir irn Einklang mit Mensch und Natur der Heilkunst zur Verfügung stellen. WELEDA AC, Postfach 1320, 73503 Schwàbisch Gmünd

WELEDA 